\title{
電子情報通信学会に関連する賞を 受賞された方を御紹介します.
}

\section{第69回 (平成24年度) 論文賞}

平成24年度は学会全体で 12 編の論文が論文賞を受賞しました。 そのうち, 基礎・境界ソサイエティでは 3 編 の論文が受賞しています，受賞した3編の論文の著者にインタビューしました.

\section{古賀引樹(筑波大)}

「Four Limits in Probability and Their Roles in Source Coding」

\section{Q. 論文賞を受けられた御感想をお聞かせ下さい.}

名誉ある賞を頂くことになり，大变うれしく思っております，同時に，身が引き締まる思しも感じてお ります，この賞を受賞するにあたって審査頂いた論文賞委員会の方々，掲載時にお世話になった編集委員 の方, 査読者の方々にこの場をお借りして御礼申し上げたいと思います

\section{Q. 論文賞を受けられた御研究について教えて下さい.}

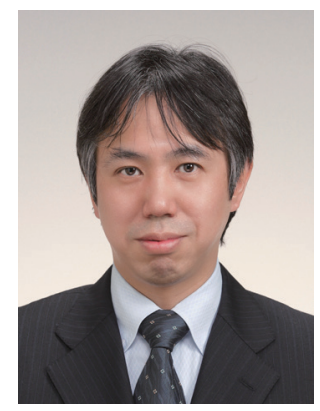

学部しベルの情報理論では，情報源の無記憶性の仮定の下で符号化の性能を議論します，固定長符号化をするときは, レ一トの 下限となるのはエントロピーです，このエントロピーは，自己情報量の期待值として定義される量です，本研究で扱ったのは，無 記憶性などの仮定のない，極めて一般的な情報源の固定長符号化ですが，このような情報源に対する符号化の性能は，期待值では なくて, 自己情報量の分布から決まる量で特徵付けられます，分布の特徵量として，これまでは分布の左端と右端の二つがよく用 いられてきましたが, 本研究では今まで余り用いられてこなかった別の形の左端と右端の二つに着目して，その重要性を幾つかの 形で明らかにしました。

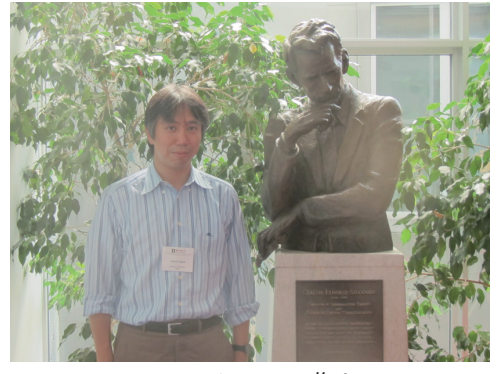

MIT のシャノン像と

Q. 現在, 御興味を持たれている研究テーマを教えて下さい.

情報スペクトルの理論も誕生から20年を迎えていますが，基本的なことでもまだ知られ ていないことがあったり，面白さは尽きません，微力ですが，情報スペクトルの更なる広が りを少しでも垣間見れればと思っています，また，情報理論の中でも情報セキュリティ色の 強い分野になりますが, 秘密分散法や電子指紋符号といったテーマにも興味を持っています これらは定式化は異なりますが, 共に悪事を働く複数の不正者を(少なくとも理論上では) 一網打尽にできるという共通点があり，面白さを感じています，

\section{Q. 今後の抱負をお聞かせ下さい.}

今後も情報理論関連分野の面白そうなテーマを精力的に研究したいと思っています，とはいえ，喜安善市賞受賞者の名前に恥じ ない研究をしようと思うと何もできなくなりそうなので, これまでと同じように，平常心で，興味を持ったテーマに対して，数理 的な視点から面白いアプローチができればと思っています，また，個性的な学生が研究室に配属されていますので, 彼らの能力や 寸能を伸ばすためのサポートを充実していければと思っています．

\section{Q.読者へのメッセージをどうぞ!}

今後とも御指導, 御助言のほど, よろしくお願い申し上げます．

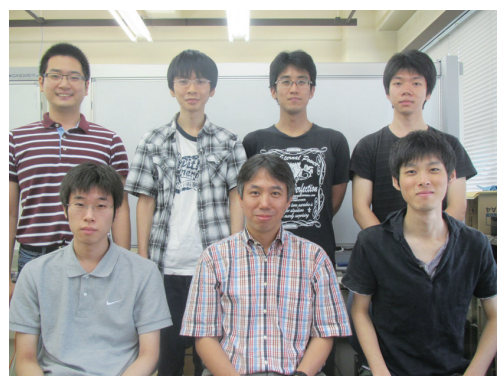




\section{Lovic Eric Gauthier (九大), 石原 亭 (九大)}

「Implementation of Stack Data Placement and Run Time Management Using a Scratch-Pad Memory for Energy Consumption Reduction of Embedded Applications」

\section{Q. 論文賞を受けられた御感想をお聞かせ下さい.}

名誉ある賞に選ばれたことを大変光栄に思います，共著者である石原先生をはじ め有益な御指導を頂いた皆様に心より感謝致します。石原先生と一緒に研究した期 間は短かかったですが, いろいろなことを学ぶことができ, 大変お世話になりまし た.（ゴーチェ）

受賞の対象亡なった論文は, 名古屋大学の高田広章先生, 立命館大学の冨山宏之 先生, 京都大学の高瀬英希先生及び東芝の深谷哲司様をはじめ多くの方々との共同 研究の成果をまとめたものです，共同研究の中で有益な助言を頂いた皆様に心より 感謝致します。（石原）

（当該論文発表時, 同じ研究室で研究プロジェクトに取り組んだ著者つ名ですが, 現在はその研究室とは異なる別々の組織に所属しています.直接会う機会がなくな り寂しく思います.)

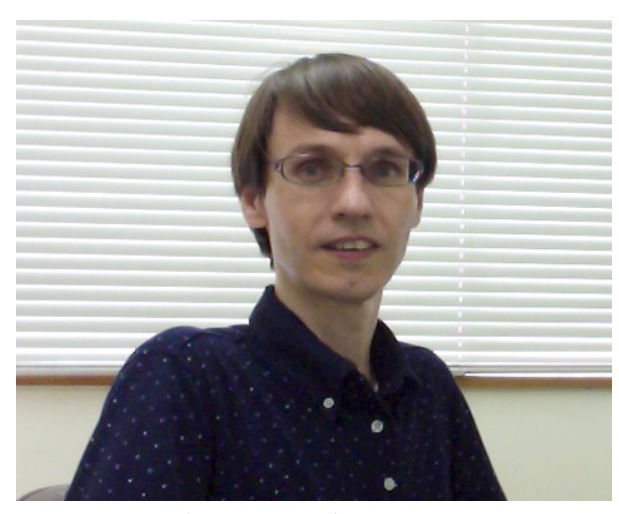

ゴーチェ・ロヴィックさん 新天地の有明高専にて

\section{Q. 論文賞を受けられた御研究について教えて下さい.}

スマートフォンに代表される携帯組込みシステムはバッテリーの連続駆動時間が製品価值を左右します. 中でも非常に大きな電 力を消費するプロセッサとメモリは組込みシステムのキーデバイスです，本研究は，プロセッサとメモリの低消費電力化を狙った ものです．この研究のポイントはスクラッチパッドメモリ (以下SPM) と呼ばれる小形のチップ内蔵メモリを有効利用することに あります，SPMはサイズが小さく，アクセス当りのエネルギーが小さいので, 繰り返しアクセスするデータをこのSPMに格納 して使用すればアプリケーションの消費エネルギーを大幅に削減できます。しかし, SPMはサイズが小さいためアプリケーショ ンが必要とするデー夕を一度にSPMに格納することはできません，そこで本研究では，SPMに格納するデー夕を効率良く時分 割で置き換える手法を開発し, アプリケーションの実行に際してプロセッサとメモリが消費するエネルギ一を大幅に削減すること に成功しました.

\section{Q. 現在, 御興味を持たれている研究テーマを教えて下さい.}

CPUなどの八ードウェアとOSなどのシステムソフトウェアをまとめて高い抽象度でモデル化する技術の研究に取り組んでい ます．例えば,システム全体の実行時間と消費電力を正確に表現するモデルの記述方式を検討しています．これにより,コンピュー タシステム全体を高速にシミュレーションすることができ, 更には短期間で最適な八一ドウェアとソフトウェアを合成することが できます.（ゴーチェ）

環境から取り入れた自然エネルギーでコンピュータを持続動作させる仕組みの研究に取り組んでいます。真にいつでもどこでも 使えるコンピュータの実現を目指しています。（石原）

\section{Q. 今後の抱負をお聞かせ下さい.}

今年の4月から有明工業高等専門学校に教員として勤務することになり教育の任務が多くなりました。 これまで培った経験を教 育に生かして行こうと思います.研究についても,現在取り組んでいるテーマで有益な社会貢献をしたいと思っています.（ゴ一チェ）

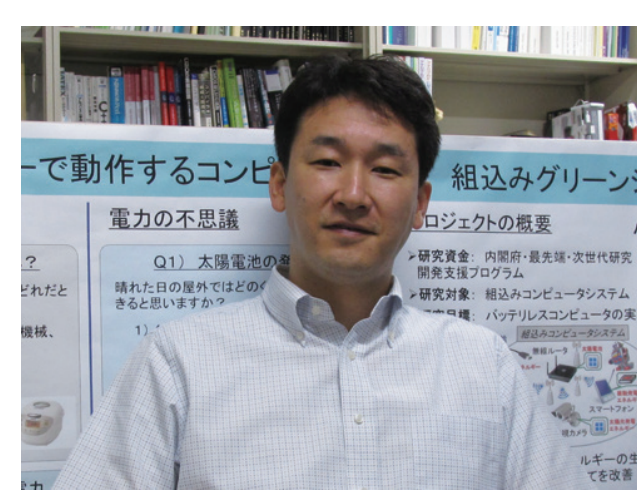

石原亨さん

新天地の京都大学にて

エネルギー・食糧・水の供給危機の問題は我々が取り組むべき今世紀最大の問 題です．情報通信技術を駆使すればこれらの問題を緩和できると思っています 社会に溶け込み，それとなく人の生活を持続可能で安全·安心にするような情報 通信技術を作り上げたいと考えています。（石原）

\section{Q. 読者へのメッセージをどうぞ !}

これまで私は，画期的なアイデアというよりも既存技術の改善に基づいて研究 を進めてきました，それは魅力的と思えないかもしれませんが，小さくても日々 新しい発見があるので非常に楽しいです，本論文のテーマである省エネルギー化 の研究は, アプリケーションレベルの技術に関してはまだまだ研究の余地が残さ れていると思います。暇を見つけて研究を続けたいです（ゴ一チェ） 
これまでに, イラン, 中国, フランス (ゴーチェ・ロヴィックさん), オーストラリア, 韓国の研究者と研究を介して深く関わ り多数の論文を共同執筆することができました，海外の方との共同研究では, 研究内容だけでなくその国の文化も知ることができ, 非常に刺激的です．研究会などで私を見かけた海外の研究者の方は是非お気軽にお声かけ下さい。（石原）

\section{清水 孝一 (三菱電譏)，鈴木 大輔 (三菱電機)，粕谷 智已 (三萲電機)}

「Glitch PUF: Extracting Information from Usually Unwanted Glitches」

\section{Q. 論文賞を受けられた御感想をお聞かせ下さい.}

栄誉ある賞を頂いて, 誠に光栄です. 数ある論文の中から選んで頂けたの も何かの御緑だと思います，日頃からお世話になっている方々をはじめ, 皆 様に感謝致します。

\section{Q．論文賞を受けられた御研究について教えて下さい.}

同じ設計図に従い，同じ方法で製造した製品であっても，製造ばらつきに よる個体差が生じます，そのような個体差を，製品の固有IDとして抽出す るPUF (パフ) と呼ばれる技術があります。PUFで抽出した固有IDは，暗 号や認証などの情報セキュリティ機能に必要な, 秘密情報としての利用が期 待されています，本論文は，半導体デバイス上の回路に生じるグリッチと呼 ばれる現象を固有IDとして抽出するPUF方式を提案しました，従来方式の 幾つかに対し，機械学習を利用して固有IDのパターンを推測する攻撃が知 られていますが, 本方式はグリッチという非線形現象を利用することで，そ

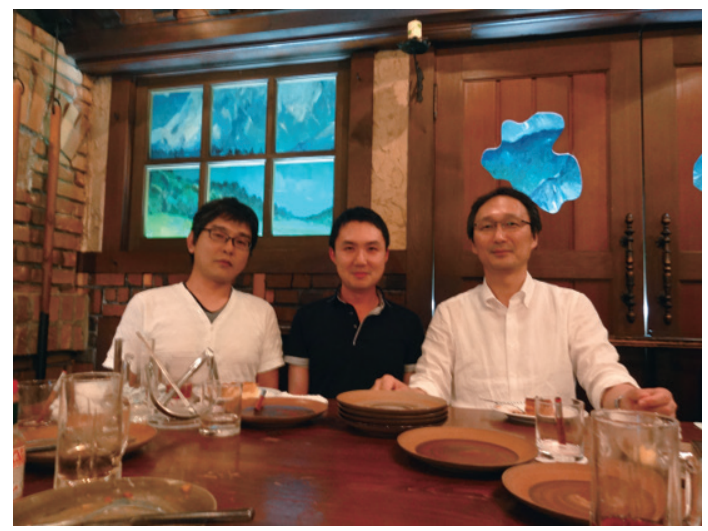

受賞記念の宴にて

(左から、鈴木さん・清水さん・粕谷さん) のような攻撃への耐性を高めています。

Q. 現在, 御興味を持たれている研究テーマを教えて下さい.

半導体のプロセスルールの違いがもたらす本方式への影響を調べています．プロセスルールによってグリッチの発生傾向が異な るので, その違いを定式化し, 方式の改良につなげたいと考えています.

\section{Q. 今後の抱負をお聞かせ下さい.}

研究テーマに対する興味が一番のモチベーションなので, 今後も自分たちの興味を大切にして研究に取り組みたいと思います. また, 微力ながら, 研究活動を通じて社会に貢献していきたいと思います.

Q. 読者へのメッセージをどうぞ！

分野を問わず皆様とどこかでつながることができれば幸いです。よろしくお願し致します． 